\title{
Pollen- and charcoal-based evidence for climatic and human impact on vegetation in the northern edge of Wuyi Mountains, China, during the last 8200 years
}

\author{
Ting Ma, ',2 Pavel E Tarasov, ${ }^{2}$ Zhuo Zheng,' Aiyan Han' and \\ Kangyou Huang'
}

\begin{abstract}
Pollen and charcoal records derived from the sediment core of Lantianyan (LTY) peat bog, Northern Wuyi Mountain chains, eastern subtropical China, provide valuable information of landscape evolution caused by both climatic variation and anthropogenic activities over the past 8200 years. Our results reveal fluvial and lacustrine deposition between c. 8200 and 5600 cal. yr BP. The high proportion of pollen from evergreen broadleaved forests (e.g. Quercus and Castanopsis) and Alnus trees, a taxon frequently occurring in mountain wetlands, implies a humid interval, which is consistent with the Holocene moisture maximum in eastern China. After $5600 \mathrm{cal}$. yr BP, the spread of the wooded swamp taxon, Glyptostrobus, suggests shallow water conditions and peat formation caused by gradual drying. The drying trend generally corresponds with the speleothem isotope record from this region, revealing a weakening East Asian summer monsoon (EASM) due to a decrease in Northern Hemisphere summer insolation (and in air temperature). Peaks in the abundance and concentration of Glyptostrobus pollen at c. 4600-4400 cal. yr BP and c. 3300-3000 cal. yr BP suggest two periods of swamp expansions, which coincide with the drought intervals revealed by the speleothem records. The LTY pollen and charcoal record demonstrates that human-induced land cover change was negligible before $3600 \mathrm{cal}$. yr BP. We consider the first signal of intensive human activity and landscape clearing to be the noticeable increase in charcoal particles at around $3600 \mathrm{cal}$. yr BP. This anthropogenic impact is followed by a dramatic decrease in arboreal pollen and increase in Poaceae pollen percentages, likely reflecting a transition to rice-paddy agriculture in the study area.
\end{abstract}

\section{Keywords}

anthropogenic influence, charcoal, Holocene, pollen analysis, sedimentary environment, Zhejiang Province

Received 13 January 2016; revised manuscript accepted 19 January 2016

\section{Introduction}

The East Asian summer monsoon (EASM) controls precipitation regimes in subtropical China and has prominent impacts on regional vegetation characteristics (Webster et al., 1998; Zhang et al., 2011). Therefore, pollen analysis of peat and lake sediments from this region may provide important information for reconstructing natural variability in monsoonal cycles and understanding human-environment interactions.

High-resolution stalagmite $\delta^{18} \mathrm{O}$ records from Chinese caves illustrate general patterns of monsoon variability during the Holocene and provide reconstructions of precipitation amounts associated with the strength of the EASM circulation (Cosford et al., 2008; Hu et al., 2008; Wang et al., 2005). During the early Holocene, the EASM strengthened and the late Holocene attenuation followed orbitally induced changes in the Northern Hemisphere summer solar insolation and associated shifts of the Intertropical Convergence Zone (ITCZ) (COHMAP Members, 1988; Kutzbach, 1981). The weakened monsoonal circulation caused a climatic shift towards a cooler and more arid period, according to a great number of studies from China (An et al., 2000; Hong et al., 2000; Ma et al., 2009; Tarasov et al., 2006; Zhang et al., 2011; Zhao et al., 2007). These millennial-scale general trends were complicated by shorter (i.e. century- to decadal-scale) variability, whose underlying mechanisms are still under debate (Cosford et al., 2008; Wang et al., 2005).

In comparison with the central and northern parts of China, the Holocene vegetation history of eastern subtropical China, an area largely affected by the EASM, is studied in less detail (Huang et al., 2014; Yue et al., 2012; Zhao et al., 2009). Pollen records from Dahu peat demonstrate that evergreen broadleaved forests expanded from 11,600 to 6000 cal. yr BP (calendar ages before present are consistently used throughout the text), marking the Holocene optimum, and that ferns and herbs increased rapidly after 6000 cal. yr BP, suggesting a drier climate (Zhou et al., 2004). Pollen records from Fujian Province also reveal a retreat of

'School of Earth Science and Geological Engineering, Sun Yat-Sen University, China

${ }^{2}$ Section Paleontology, Institute of Geological Sciences, Free University of Berlin, Germany

\section{Corresponding author:}

Zhuo Zheng, School of Earth Science and Geological Engineering, Sun Yat-Sen University, 510275 Guangzhou, China.

Email: eeszzhuo@mail.sysu.edu.cn 

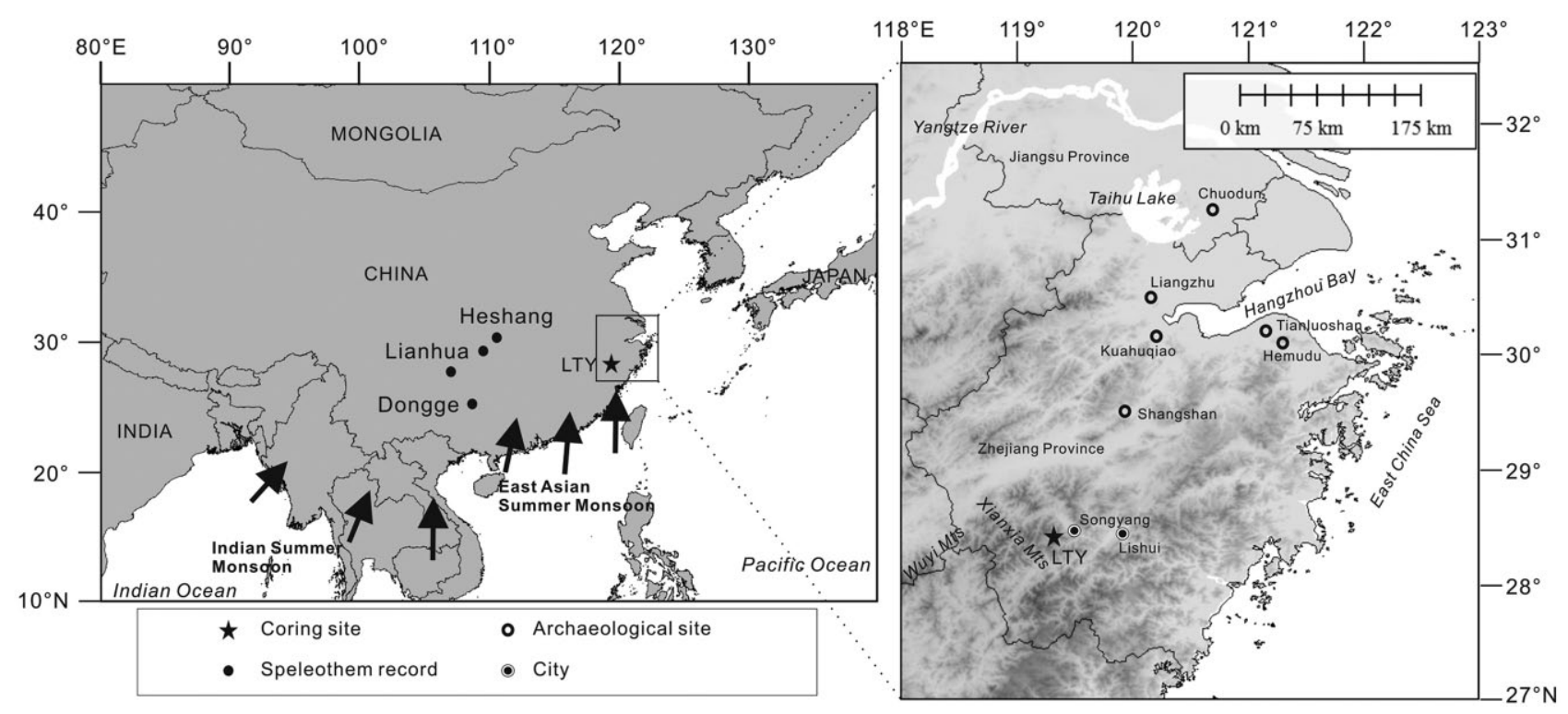

Figure I. Location of the LTY core site and speleothem and archaeological records mentioned in this paper.

the mixed forest vegetation after the middle Holocene (Yue et al., 2012, 2015). However, such palaeobotanical records from eastern subtropical China are scarce.

In point of view of human impact on vegetation during the Holocene, the low-elevated alluvial plains around Hangzhou Bay on the East China Sea in northeast Zhejiang Province, including the Yangtze delta, were considered as a centre for early rice (Oryza sativa) agriculture (Fuller et al., 2007, 2009; Silva et al., 2015; Wang et al., 2010). Neolithic cultures arose in this area around $8000 \mathrm{cal}$. yr BP and flourished over the following 4000 years, associated with a great number of archaeological sites. There are abundant noticeable sites such as Kuahuqiao, Hemudu, Tianluoshan, Chuodun, and Liangzhu (Figure 1), which attracted many archaeological research works as well as Holocene environmental research works (Atahan et al., 2008; Cao et al., 2006; Innes et al., 2009; Jiang et al., 2004; Qin et al., 2011; Shu et al., 2010; Stanley and Chen, 1996; Weisskopf et al., 2015; Zong et al., 2007). Moreover, Shangshan site in Zhejiang Province provides some of the earliest rice remains dated to 12,000 cal. yr BP, which drew particular attention to the Lower Yangtze valley as one probable area of earliest rice domestication (Jiang and Liu, 2006; Wang et al., 2010; Wu et al., 2014). Different from previous abundant studies mentioned above, our research focuses on a pollen record in the northern end of the Wuyi Mountain chains at very south Zhejiang Province, which is characterized by precipitous topography and has an average elevation of approximately $1000 \mathrm{~m}$. This mountainous area is located at the vital area connecting Lower Yangtze valley and Lingnan-Fujian mountain chains. Therefore, it will be of great significance to compare local Neolithic culture with agricultural civilization in lower Yangtze and hunting-gathering societies in southern China. However, Neolithic discoveries are quite limited in the vicinity regions of study site (Guojia Wenwuju, 2009) and there is also shortage of Holocene environment study. Here as well, palynological records may contribute important information about forest community and human-induced land cover changes and agricultural practices in this mountainous region.

This paper is based on a c. 8200-year record from the Lantianyan (LTY) peat bog situated in Songyang County, southern Zhejiang Province (Figure 1). Our study focuses on pollen and charcoal analyses and aims at reconstructing the environmental changes and at discussing the possible relationships with the natural EASM variability and anthropogenic activities in the region.

\section{Regional setting}

A core taken from the LTY peat bog represents a mountain wetland deposit near Zhushan village in Songyang County of southern Zhejiang (Figure 1). The LTY peat bog covers about $0.64 \mathrm{~km}^{2}$. It is located at about $900 \mathrm{~m}$ a.s.l. in a valley of the Xianxia Mountains in the northern edge of Wuyi Mountain chains.

The regional climate is dominated by the East Asian Monsoon, with frequent typhoons originating in the western Pacific between May and November. The regional mean annual temperature is $18-20^{\circ} \mathrm{C}$, with January and July mean temperatures, respectively, $6-7^{\circ} \mathrm{C}$ and $26.5-29.5^{\circ} \mathrm{C}$ and the coldest mean temperature $-6.5^{\circ} \mathrm{C}$. The mean annual precipitation varies from 1500 to $1900 \mathrm{~mm}$, with $80 \%$ of the total annual precipitation falling from March to September (Chen, 1985).

The LTY wetland vegetation communities include species of Cyperaceae, Poaceae, Sphagnaceae, Araceae, Rosaceae, Ericaceae and Alnus, among others. The regional natural vegetation is a middle subtropical evergreen broadleaved forest dominated by species of Fagaceae and Lauraceae. In the northern Wuyi Mountains, the vegetation composition along the altitudinal profile is described as follows (Institute of Botany, Academy Sinica (IBAS), 1960): below $500 \mathrm{~m}$ a.s.l. - cultivated land, brush and secondary forest associations; $500-1000 \mathrm{~m}$ a.s.l. - evergreen broadleaved forest associations dominated by Fagaceae, including Cyclobalanopsis, Castanopsis, Lithocarpus and species of Lauraceae, Theaceae, Moraceae, Elaeocarpaceae and Hamamelidaceae. Coniferous taxa occur in a few areas including Keteleeria fortunei, Taxus chinensis, Pseudolarix amabilis and Torreya grandis; $1000-1500 \mathrm{~m}$ a.s.1. - evergreen broadleaved forest, often with an admixture of deciduous taxa including Carpinus, Fagus, Acer, Tilia and Pterocarya. Conifers also occur in some areas including Tsuga longibracteata, Keteleeria fortunei and Pseudolarix amabilis. Higher elevations of this zone are often occupied by coniferous forests of Pinus taiwanensis. The understory plants include numerous ferns such as Pteridium aquilinum and Dicranopteris linearis and woody taxa such as Crataegus cuneata and Viburnum macrocephalum; above $1500 \mathrm{~m}$ a.s.1. - the mountain summits are covered by shrub vegetation dominated by Eurya spp. (Theaceae) and Rhododendron spp. belonging to Ericales.

\section{Materials and methods}

We collected a 127-cm-long core from the LTY peat bog $\left(28^{\circ} 26.040^{\prime} \mathrm{N}, 19^{\circ} 18.849^{\prime} \mathrm{E} ; 902 \mathrm{~m}\right.$ a.s.l.; Figure 2a) using a 

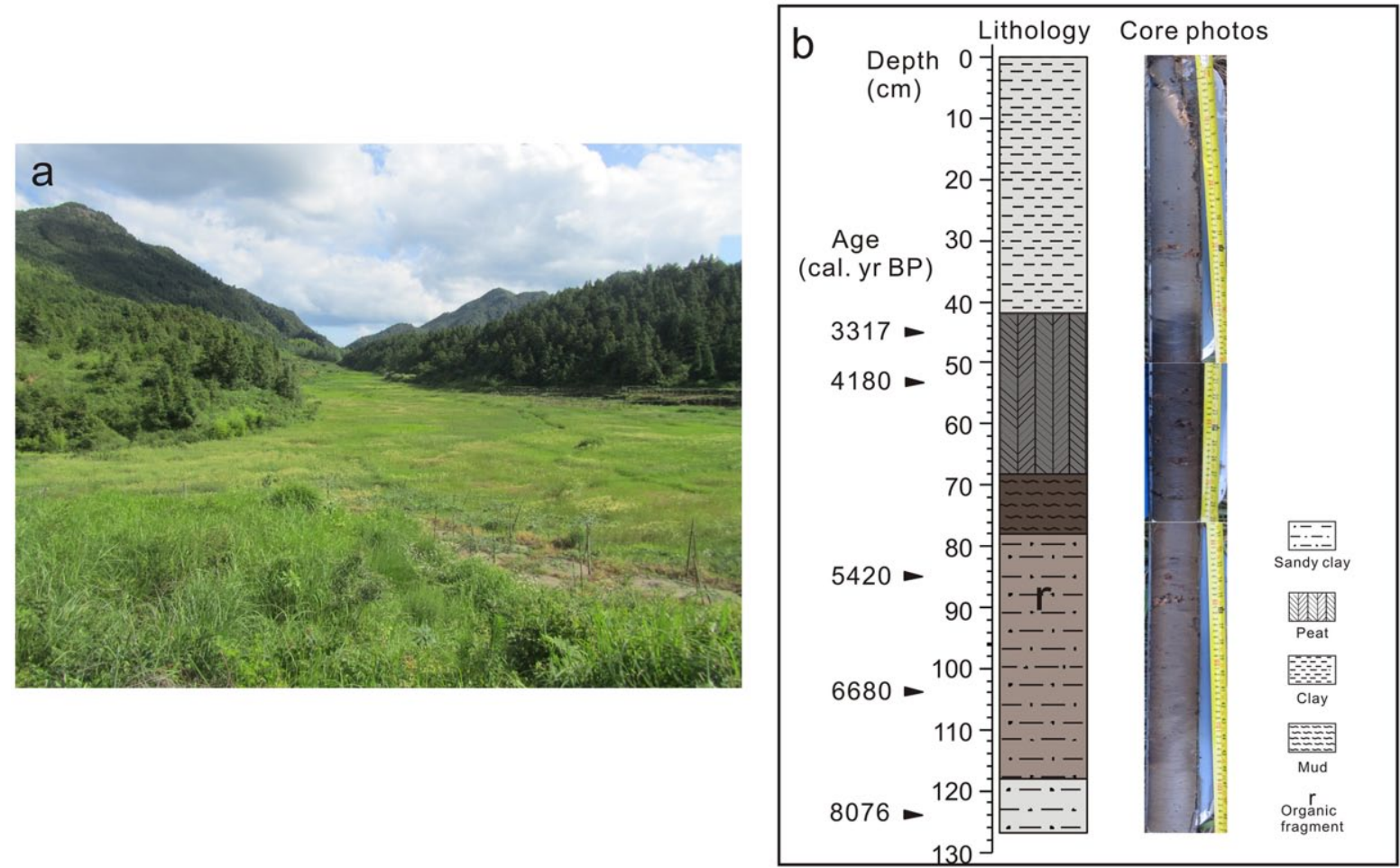

Figure 2. Composite figure showing (a) the site setting of the LTY peat bog and (b) a photograph and the schematic lithological description of the LTY sediment core.

Table I. The LTY core AMS ${ }^{14} \mathrm{C}$ dates and calibrated ages.

\begin{tabular}{|c|c|c|c|c|}
\hline Depth $(\mathrm{cm})$ & Laboratory number ${ }^{\mathrm{a}}$ & Dated material & Radiocarbon age, yr BP & Calibrated age, cal. yr BP ( $95 \%$ prob.) \\
\hline 45 & Beta 358423 & Plant remains & $3110 \pm 30 \mathrm{BP}$ & $3239-3385$ \\
\hline \multirow[t]{4}{*}{53.5} & Poz 70906 & Bulk sediment & $3785 \pm 35 \mathrm{BP}$ & $4006-4033$ \\
\hline & & & & $4080-4258$ \\
\hline & & & & $4265-4268$ \\
\hline & & & & $427 I-4287$ \\
\hline \multirow[t]{2}{*}{85} & Beta 358424 & Plant remains & $4690 \pm 40 \mathrm{BP}$ & $53|8-548|$ \\
\hline & & & & $5532-5578$ \\
\hline \multirow[t]{3}{*}{104.5} & Poz 70907 & BulkTOC & $5860 \pm 40 \mathrm{BP}$ & $6563-6592$ \\
\hline & & & & $6599-6755$ \\
\hline & & & & $6763-6778$ \\
\hline 124 & Beta 355846 & Bulk sediment & $7250 \pm 30 \mathrm{BP}$ & $8003-8162$ \\
\hline
\end{tabular}

AMS: accelerator mass spectrometry.

aBeta, Beta Analytic; Poz, Poznan Radiocarbon Laboratory.

${ }^{b}$ Calibrated dates were determined using the IntCall 3 (Reimer et al., 20I3).

'Russian' peat core (hand drill). The core sediment reveals the following lithological units (Figure $2 b$ ): $0-42 \mathrm{~cm}$ - grey clay; $42-68 \mathrm{~cm}$ - organic-rich grey-black peat, with organic fragments at 46,59 and $66 \mathrm{~cm} ; 68-78 \mathrm{~cm}$ - black-dark brown humic mud; $78-118 \mathrm{~cm}$ - humus-rich brown-grey sandy clay, with organic fragments at $90 \mathrm{~cm} ; 118-127 \mathrm{~cm}$ - grey sandy clay.

Five bulk samples from the LTY core were sent for accelerator mass spectrometry (AMS) radiocarbon dating (Table 1). Three samples were AMS-dated at the laboratory of Beta Analytic Inc., Miami, US, and two samples were AMS-dated at the Poznan Radiocarbon Laboratory, Poland. All ${ }^{14} \mathrm{C}$ dates were calibrated using the IntCal13 (Reimer et al., 2013). The best fit age model for the LTY core (Figure 3) was constructed using the Clam 2.2 software package (Blaauw, 2010).

We used loss on ignition (LOI) at $550^{\circ} \mathrm{C}$ data to estimate the organic content of the core sediments. The method is based on determination of weight percentage organic matter in sediments, which is measured by weighing the samples before and after heating in a muffle furnace (Bengtsson and Enell, 1986; Heiri et al., 2001). A total of 62 samples (at 1 or $2 \mathrm{~cm}$ intervals) were picked from the core. In order to obtain the dry weight, all samples were mashed and dried in a muffle furnace at $105^{\circ} \mathrm{C}$. Later, organic matter was combusted for $2 \mathrm{~h}$ at $550^{\circ} \mathrm{C}$. The LOI is calculated using the following equation:

$$
\mathrm{LOI}_{550}=\left(\frac{\mathrm{DW}_{105}-\mathrm{DW}_{550}}{\mathrm{DW}_{105}}\right) * 100
$$

where $\mathrm{LOI}_{550}$ is $\mathrm{LOI}$ at $550^{\circ} \mathrm{C}$ in percentage of the weight of the solid particles, $\mathrm{DW}_{105}$ is dry weight of the sample before combustion and $\mathrm{DW}_{550}$ is dry weight of the sample after heating to $550^{\circ} \mathrm{C}$.

Another proxy for organic content in lacustrine sediments is the greyscale of the cleaned surface of the sedimentary succession. In order to detect changes in sediment greyscale values, we used 8-bit greyscale images and Image J software (Rasband, 1997-2014). Generally speaking, low greyscale values indicate 


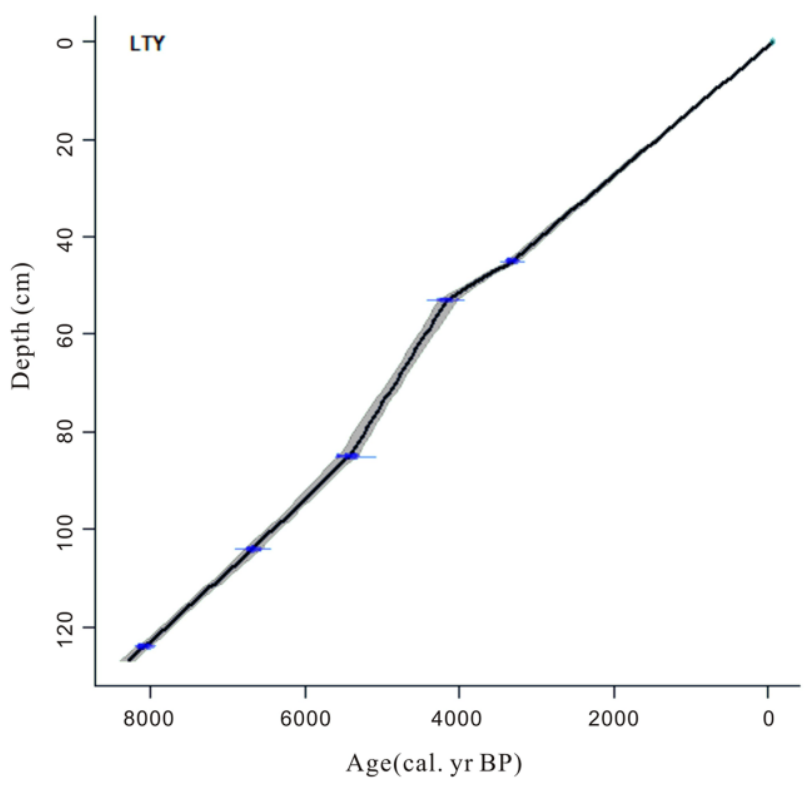

Figure 3. Age-depth model based on calibrated ${ }^{14} \mathrm{C}$ dates of the LTY core which was constructed using the Clam 2.2 software package. The black line of the plot shows the best fit age-depth model and the grey envelope of the plot shows the final $95 \%$ confidence (Blaauw, 20I0).

higher organic matter content in the sediment, while high values indicate lower organic content.

For pollen analysis, 31 discontinuous 1-cm-thick samples were taken at $4 \mathrm{~cm}$ intervals from the LTY core. Sediment samples were treated with $\mathrm{HCI}, \mathrm{KOH}$ and heavy liquid separation ( $\mathrm{ZnCl}_{2}$, density 1.9) (Nakagawa et al., 1998). Micro-charcoal particles were obtained during the pollen preparation process. A known quantity of Lycopodium spores (27,637 \pm 563 in one tablet) was added to every sample in order to estimate pollen and charcoal concentration (Maher, 1981; Stockmarr, 1971). Pollen Flora of China (Wang et al., 1995) and Tropical and Subtropical Angiosperm Pollen Morphology (Institute of Botany and South China Institute of Botany, Academy Sinica (IBSCIBAS), 1982) were used as the main references for pollen and spore taxa identification. Additionally, the modern pollen slide collection at Sun Yatsen University was used for comparison and identification of the regional taxa. At least 400 terrestrial arboreal and non-arboreal taxa pollen (AP and NAP) grains were counted from each sample. Pollen taxa percentages were calculated using the total sum of terrestrial pollen, including trees, shrubs and terrestrial herbs. Percentages of aquatics (Araceae and Cyperaceae), ferns and algae were calculated using the total sum of all palynomorphs (except charcoal) taken as $100 \%$. The pollen diagram was plotted using Tilia software (Grimm, 1991), and pollen zones were assigned by cluster analysis using CONISS (Grimm, 1987).

Micro-charcoal particles were measured and sorted into three size classes: $10-50,50-125$ and $>125 \mu \mathrm{m}$. Particles smaller than $10 \mu \mathrm{m}$ were not counted because they are probably broken fragments. Particles $>125 \mu \mathrm{m}$ are taken as evidence for local fire, while particles $<125 \mu \mathrm{m}$ represent regional fires (Clark, 1988; Whitlock and Larsen, 2001).

\section{Results}

A total of 60 pollen types were identified from the core sediments, including 38 arboreal taxa, 13 herbaceous taxa, 2 aquatic taxa, 5 fern taxa, and two types of algal palynomorphs. The main arboreal pollen types include coniferous taxa (e.g. Taxodiaceae, Tsuga, Pinus, Taxaceae, Cupressaceae), evergreen broadleaved trees (e.g. Quercus-evergreen, Castanopsis, Euphorbiaceae, Ilex,
Myrsinaceae, Sapindaceae, Symplocaceae, Myricaceae), deciduous broadleaved trees (e.g. Alnus, Fagus, Liquidambar, Salicaceae, Betula, Ulmus, Carpinus) and shrubs (e.g. Celastraceae, Ericaceae, Viburnum, Eurya). Herbaceous pollen is mainly represented by Artemisia, Caryophyllaceae, Poaceae and Apiaceae. The aquatic taxa include Araceae and Cyperaceae. The main spore types are non-differentiated Monolete and Trilete spores and Dicranopteris. The most common algae are Concentricystes. The pollen diagram has been divided into five local pollen assemblage zones, identified by the cluster analysis (Figure 4):

Zone $5(127-116 \mathrm{~cm} ; \mathrm{c}$. $8200-7500 \mathrm{cal}$. yr BP). This zone is characterized by high percentages of both evergreen broadleaved and deciduous broadleaved AP types. It is clearly dominated by Quercus-evergreen (40\%) and Alnus (42\%) pollen. Castanopsis is also common. Coniferous Tsuga and Pinus occur frequently. Small Poaceae grains $(<34 \mu \mathrm{m})$ and Monolete spores are present.

Zone 4 (116-88cm; c. 7500-5600 cal. yr BP). This zone reveals high percentages of Alnus and Quercus-evergreen pollen. There is a significant increase in ferns (i.e. Monolete spores). Tsuga becomes more abundant.

Zone 3 (88-49 cm; c. 5600-3740 cal. yr BP). In this zone, Tsuga pollen and fern spore percentages decrease to very low values. Pollen concentration increases noticeably. Taxodiaceae (Glyptostrobus) slightly increases at the beginning of this zone. During the second half of this zone there is a larger increase in this taxon. Accompanying the growth in Taxodiaceae (Glyptostrobus), pollen grains of temperate deciduous trees (Salix, Betula, Ulmus, Fagus, Carpinus), evergreen shrubs (including Ericaceae, Viburnum, Eurya) and vines (Celastraceae) are present. Cyperaceae also slightly increases in abundance at the upper part of zone 3, and pollen percentages of Alnus and Quercus-evergreen decrease.

Zone $2(49-28 \mathrm{~cm} ;$ c. $3740-2100 \mathrm{cal}$. $y \mathrm{r} \mathrm{BP})$. There is a noticeable increase in Taxodiaceae (Glyptostrobus) and Quercusevergreen pollen concentration at the beginning of this zone, followed by a rapid decrease in them. This is associated with an increase in Alnus and fern taxa percentages. Monolete spores and Dicranopteris make up nearly $40 \%$ of the total palynomorph assemblage at upper part of zone 2 .

Zone 1 (28-0 cm; c. 2100 cal. yr BP-present). This zone is characterized by a considerable decline in AP, that is, Quercus and Alnus, paralleled by a sharp increase in NAP. Fern spores remain abundant. Although AP is generally low, Pinus increases to around $30 \%$ of the terrestrial pollen. The NAP is predominated by Poaceae pollen, which also includes the grain size categories of $<34 \mu \mathrm{m}(17 \%)$ and $34-40 \mu \mathrm{m}(20 \%)$. Artemisia and Cyperaceae pollen and Concentricystes are also common.

Charcoal concentration remains extremely low and shows no change through $127-49 \mathrm{~cm}$ of the core. However, the upper part of the core reveals a dramatic change, with both large charcoal particles $(>125 \mu \mathrm{m})$ and small particles $(<125 \mu \mathrm{m})$ being abundant through $49-0 \mathrm{~cm}$. More specifically, charcoal concentration increases abruptly at $48 \mathrm{~cm}$ (around $3600 \mathrm{cal}$. yr BP) and reaches its highest value at $44 \mathrm{~cm}$ (i.e. 276,370 particles/g), and then shows several smaller peaks afterwards (Figure 5).

LOI and greyscale values show opposite trends (Figure 6), thus indicating the same trends in organic matter concentration. Between 127 and $78 \mathrm{~cm} \mathrm{LOI} \mathrm{is} \mathrm{low,} \mathrm{while} \mathrm{greyscale} \mathrm{values} \mathrm{remain}$ high. LOI increases sharply at $78 \mathrm{~cm}$ and then rapidly reaches its highest level. Between 78 and $42 \mathrm{~cm}$, LOI values remain high, while greyscale values fluctuate at low levels. In the uppermost 


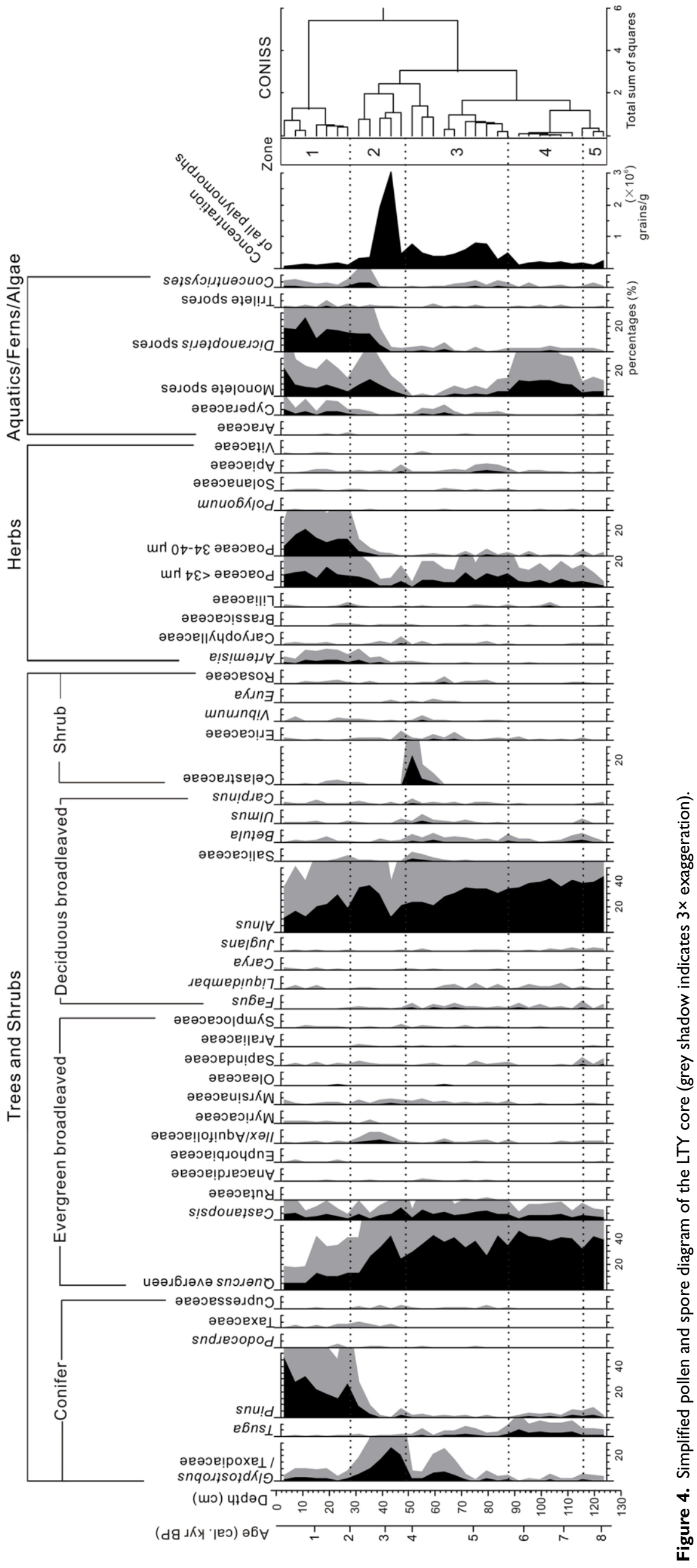




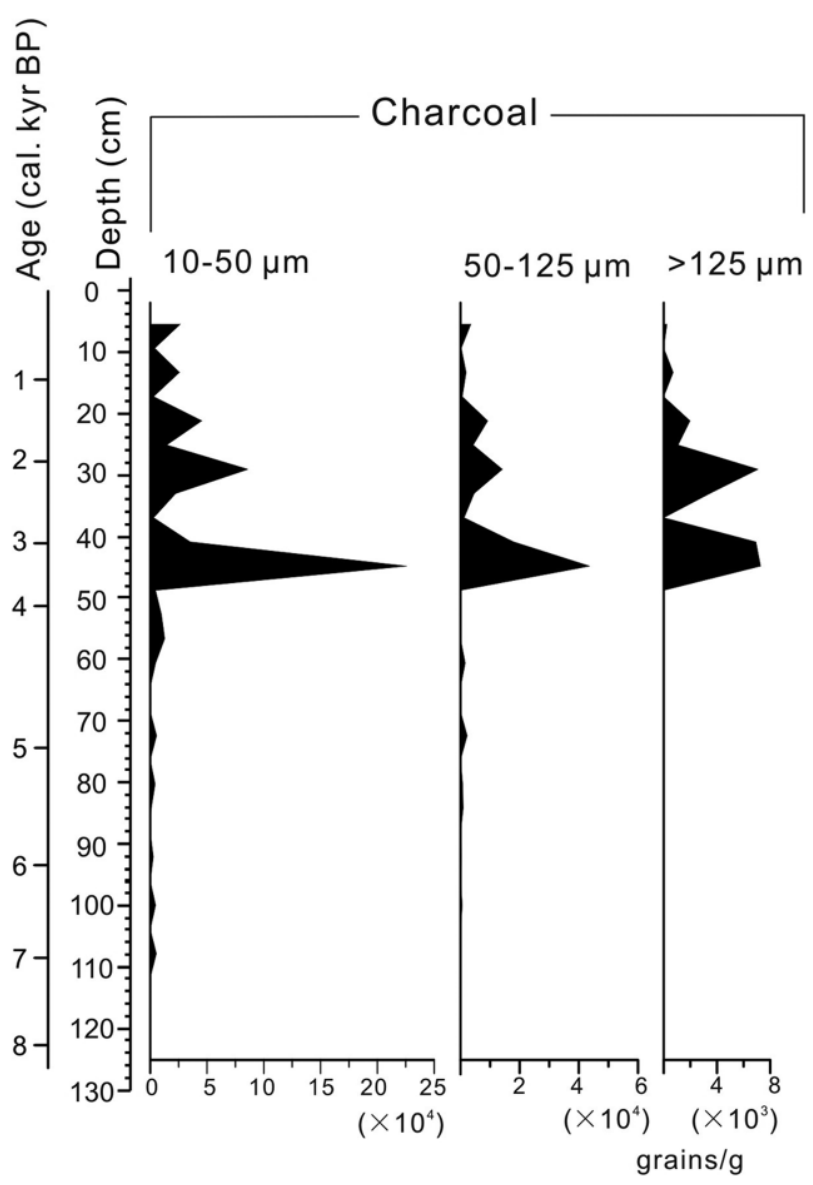

Figure 5. Charcoal diagram of the LTY core.

part of the core $(42-0 \mathrm{~cm})$, LOI drops to low values again, while greyscale values show an increase.

\section{Interpretations and discussion}

\section{Local vegetation and sedimentation environments}

In subtropical China, the hygrophilous species Alnus trabeculosa occurs in mountainous wetlands (Wu, 1980). The genus Glyptostrobus (Taxodiaceae), commonly known as water-pine, includes the species Glyptostrobus pensilis, which is considered as a typical wooded swamp taxon that was widespread on lowlands in east subtropical China during the Holocene (Peng et al., 2015). Their distribution patterns are mainly governed by hydrological factors. Glyptostrobus commonly grows on flooded or waterlogged soils and tends to occupy river deltas, swampy lake and pond shores, and swamps (Wu and Raven, 1999). The genus Alnus contains four major species in China, which naturally grow along riverbanks and stream sides or in valley bottoms within subtropical mountainous areas (Huang et al., 2014; Wu and Raven, 1999). Alnus-dominated communities in subtropical China may also represent secondary forests that appear after deforestation (Huang et al., 2014; Jiang, 1980; Li et al., 2008). In the LTY core, Alnus and Glyptostrobus have different ecological interpretations, the first taxon is adapted to riverbanks or lakeside environments and the second prefers shallow water conditions. This implies that high proportion of Alnus (type A. trabeculosa) agrees with the sedimentary facies representing fluvial and lake coastal environment, and Glyptostrobus indicates that autochthonous wooded swamp forest communities existed.

Changes in fern spores and total pollen concentration may reflect changes in hydrological conditions and sedimentation rates (Zheng and Li, 2000). High Pteridophyte spore abundance in zone 4 may suggest strengthened stream transportation and sedimentation and may indicate fluvial-lacustrine environments. The evident increase in pollen concentration in zone 3 indicates hydrologic changes from active fluvial-lacustrine to stable water regimes, under which sediment accumulation always shows higher pollen concentration values and better preservation (Zheng and $\mathrm{Li}, 2000$ ).

The palynological and sedimentological analysis of the LTY core reveals that both lithology and pollen assemblages vary significantly during the last 8200 years. The local environmental history can be divided into three main phases (Figure 6).

From c. 8200 to $5600 \mathrm{cal}$. yr BP, the area around the study site was covered by dense forest revealed by high proportions of AP. High frequencies of evergreen Quercus and Castanopsis pollen and extremely low percentages of conifers reveal a warm and wet climate supporting dominance of subtropical evergreen broadleaved forests. The grey sandy clay sediment points to a greater water supply and alluvial and/or lacustrine sedimentary environments. Relatively low taxonomic richness is also typical for climax forest vegetation. Abundant fern spores likely point to a near shore environment and greater input of surface runoff. The local humid conditions and near shore environment would have supported growth of Alnus forest with ferns in the understory. Occurrence of Tsuga pollen in the pollen assemblage suggests that this temperate conifer, which generally prefers well-drained soils, likely grew in the valley near the site.

After c. 5600 cal. yr BP, the site experienced a remarkable change in sedimentary environments indicated by a transition from sandy clay to peat-like deposits. The observed changes in the lithology is complemented by a considerable increase in LOI values and results of greyscale analysis, indicating high organic content of the sediment and a marshy environment at the study site between c. 5100 and $3000 \mathrm{cal}$. yr BP. This interpretation is supported by the results of the pollen analysis. Both increase in pollen concentration and taxonomic richness suggest a stagnant hydrological regime. Glyptostrobus pollen percentages show an increase and Alnus percentages decrease, reflecting an expansion of waterlogged soil and swampy environments more favourable for Glyptostrobus. This change could be the result of internal hydrological variation of the valley or/and decrease in moisture supply associated with the summer monsoon rainfall. Consistently, two peaks in Glyptostrobus pollen percentages (at $c$. 4600-4400 cal. yr BP and c. 3300-3000 cal. yr BP) may represent two intervals of swamp expansion associated with locally or/ and regionally drier environments.

The interval after c. 3000 cal. yr BP experienced distinct changes in pollen assemblages and in charcoal concentration, reflecting changes in vegetation and local and regional fires. AP percentages decrease dramatically in association with an abrupt decline in evergreen Quercus and Taxodiaceae, representing decline in natural forest cover. Meanwhile, the Pinus pollen percentage curve shows a sharp increase, coupled with the expansion of pines and other pioneer taxa, such as Dicranopteris and Artemisia. In regions with wet monsoon climate (such as subtropical China), such changes in the pollen assemblage and an abrupt increase in charcoal concentrations are most likely associated with intensified anthropogenic activities, including forest clearance and slash-and-burn agriculture (e.g. Huang et al., 2014; Yang et al., 2012). This is accompanied by a noticeable increase in Poaceae pollen percentages, especially the type with a grain size of 34-40 $\mu \mathrm{m}$, which also points to the possibility of wet rice cultivation. Measurements of Poaceae pollen grains from top soil surface samples from modern rice fields of double-cropping rice agriculture in the study region of subtropical China show that 34-40 $\mu \mathrm{m}$ is the typical size range for identifying domesticated rice in fossil pollen samples (Yang et al., 2012). The identified change in the core lithology (i.e. from peat to clay) and sediment characteristics may also be related to human activities, for example, managing 


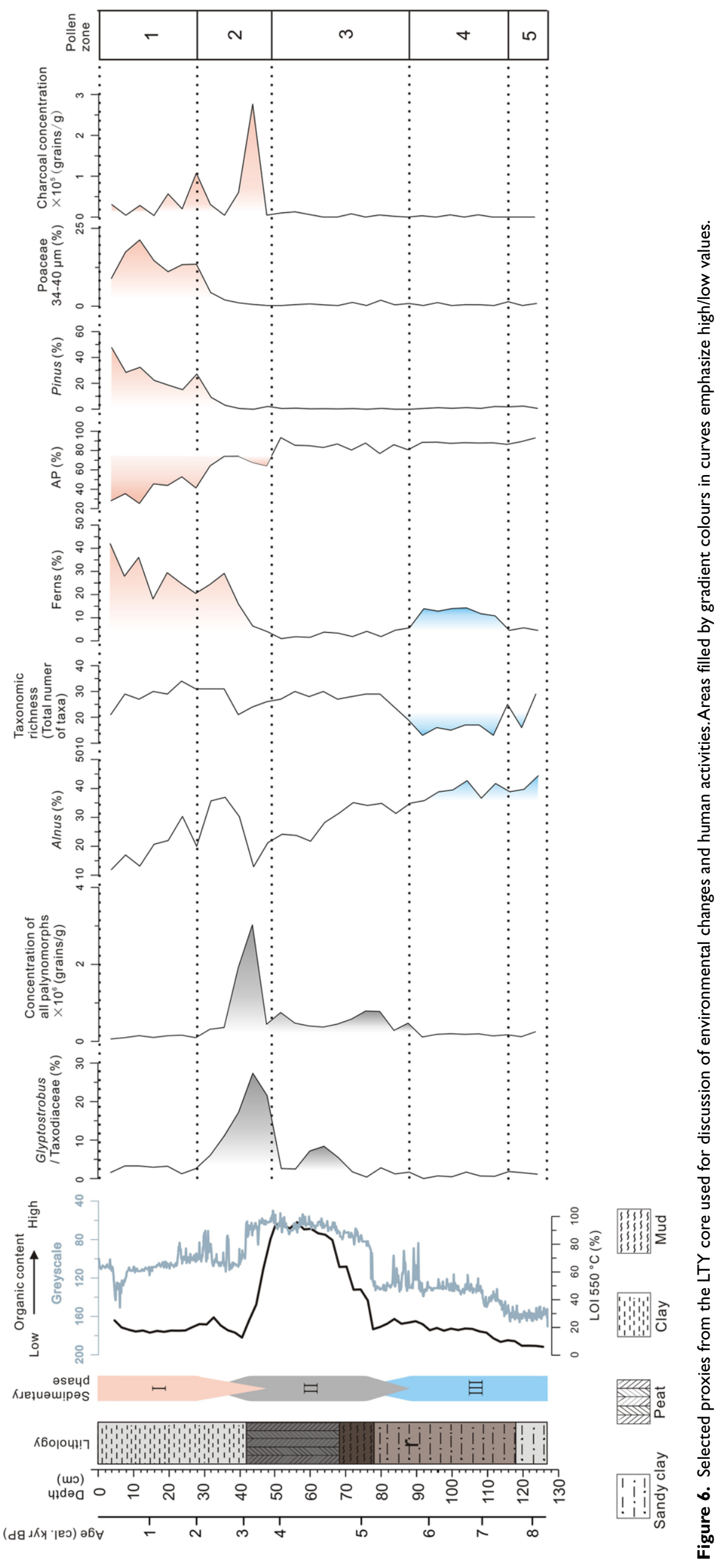




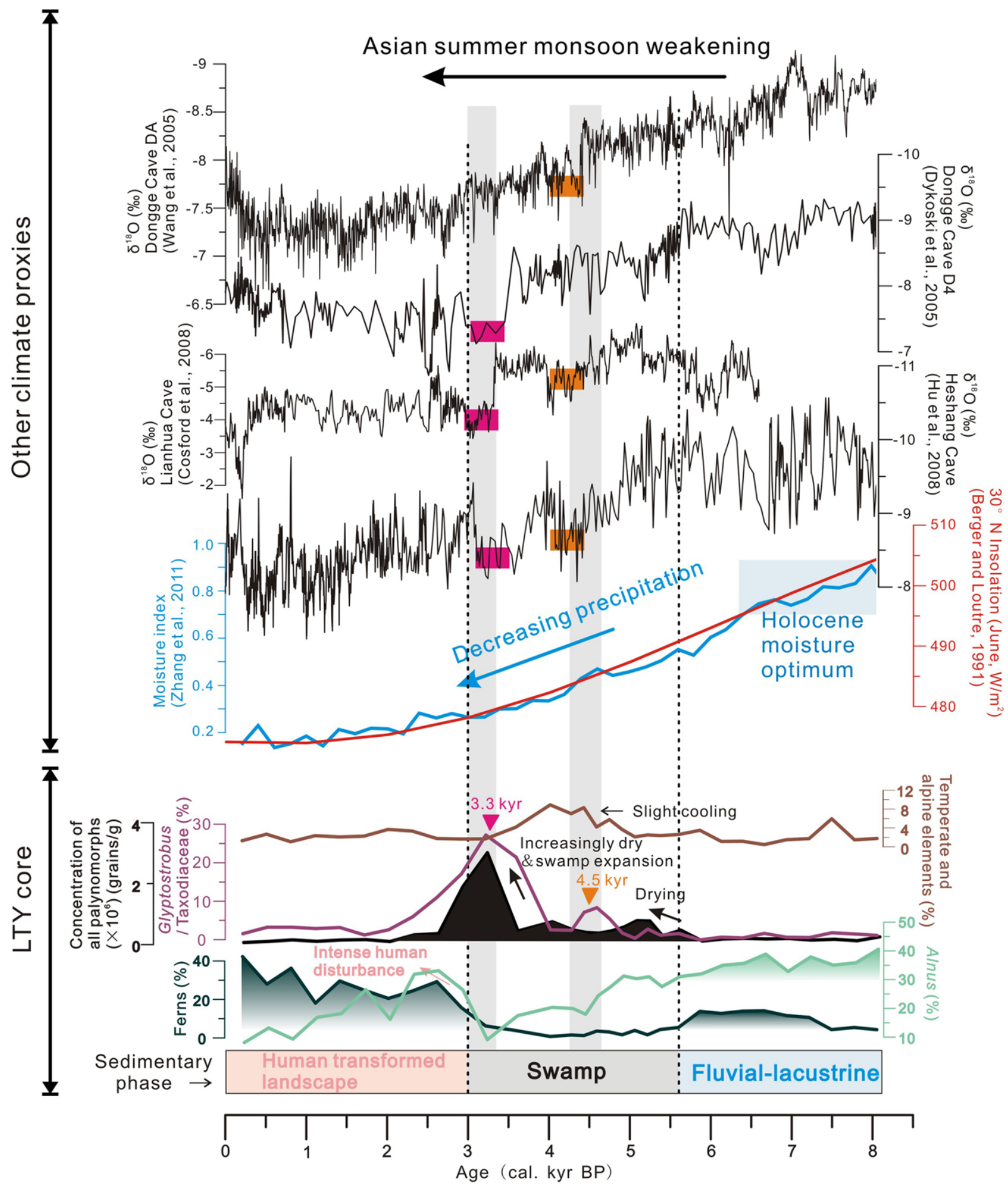

Figure 7. Key environmental proxies from the LTY core along with several other climate proxies representing the Asian summer monsoon domain discussed in this study. Temperate and alpine elements include Salix, Betula, Ulmus, Fagus, Carpinus, Ericaceae, Viburnum and Eurya.Vertical grey bands indicate dry spells recorded in LTY. Areas filled by gradient colours below Alnus and ferns curves emphasize high values.

the water flow necessary for wet rice cultivation. The increase in Cyperaceae and Alnus pollen percentages provides support for this hypothesis. Thus, wild grasses and sedges are typical components of wetland communities and rice paddies, while alder trees naturally prefer riverside environments.

\section{Holocene climate changes and regional correlations}

The fluvial-lacustrine sediment facies and the dense subtropical forest recorded in the LTY core between c. 8200 and 5600 cal. yr BP fall well within the interval of the strong monsoon phase before middle Holocene, associated with heavier monsoon precipitation and warmer climate than present. This phase is consistent with the
Holocene moisture optimum in the monsoonal regions of China (Zhang et al., 2011) (Figure 7). Other investigations from eastern subtropical China have yielded similar results with our study. Pollen records from Fujian (Yue et al., 2012) and Taiwan (Lee et al., 2010; Liew et al., 2006b) also reveal an expansion of subtropical evergreen broadleaved forest between 8000 and 5000 cal. yr BP. Pollen and geochemical data of Dahu peat in Jiangxi Province (Zhou et al., 2004) indicate the highest precipitation occurred between 10,000 and 6000 cal. yr BP as well.

After $5600 \mathrm{cal}$. yr BP, the development of stagnant swampy environments may suggest a general drying trend, resulting from the EASM weakening which is in response to the southward migration of the ITCZ and diminishing summer insolation in the 
Northern Hemisphere (COHMAP Members, 1988; Haug et al., 2001; Kutzbach, 1981) (Figure 7). The drying trend could be seen by some other developments of swamps in the region. A similar shift in environment from fluvial-lacustrine to eutrophic swamp at around $6000 \mathrm{cal}$. yr BP and a similar interpretation were presented based on sedimentary records from Dahu peat (Zhou et al., 2004). Likewise, deposits of Chitsai Lake in Taiwan also experienced a change from mud to peat at $c .4890 \mathrm{yr}$ BP (Liew et al., 2014). In our study, timing of the first peak in Glyptostrobus pollen percentages (i.e. primary expansion of the local swamp) closely matches the so-called $4.5 \mathrm{kyr}$ BP cooling event in the North Atlantic records (Bond et al., 2001) and is broadly synchronous with the noticeable weakening of the EASM (Wang et al., 2005). This weak Asian monsoon event is documented in the stalagmite records from China (Figure 7) and often used to explain the downfall (and even collapse) of the Neolithic culture in the drier regions of China (Wu and Liu, 2004). The second peak in Glyptostrobus pollen percentages (further expansion of the local swamp) at c. $3.3 \mathrm{kyr}$ BP closely matches another phase of pronounced monsoon weakening causing droughts in the northern and western parts of China (Hong et al., 2000, 2001; Lister et al., 1991; Tarasov et al., 2006; Wei et al., 1995) and India (Leipe et al., 2014). Stalagmites from Dongge cave (D4), Heshang cave and Lianhua cave all capture this abrupt weakening of the summer monsoon (Figure 7) at the transition from the middle to late Holocene (Cosford et al., 2008). Besides the reconstructed changes in moisture supply, the LTY pollen record also reflects a cooling trend since $c .4500 \mathrm{cal}$. yr BP, as indicated by the occurrence of the cooler, deciduous taxa, such as Salix, Betula, Ulmus, Fagus and Carpinus, and the increase in sub-alpine shrub taxa (e.g. Ericaceae and Eurya) which are commonly found above $1500 \mathrm{~m}$ a.s.l. today. This cooling trend is also documented by several pollen records from Taiwan Island, which shows a cold period began at around 4000 cal. yr BP (Lee et al., 2010; Liew et al., 2006a, 2006b, 2014).

\section{Anthropogenic activities}

The $c$. 8200-year LTY pollen and charcoal records allow us to assess the history and impact of anthropogenic activities on the regional environments. High frequencies of AP and extremely low charcoal concentrations throughout zone 5 to zone 3 indicate dense subtropical forest covering the study area and suggest that the overall anthropogenic impact on the regional landscape was rather limited before c. 3600 cal. yr BP. This interpretation also reveals the fact that the scarce archaeological records of the Neolithic period in this region (Guojia Wenwuju, 2009) cannot be solely explained by insufficient archaeological research and the lack of excavations. Poaceae pollen grains which are larger than $34 \mu \mathrm{m}$ and could potentially represent cultivated rice are quite rare outside pollen zone 1 . Despite the flourish of developed Neolithic rice-based agriculture in Zhejiang Province, we suppose that in our study region, high and steep terrain, dense forest cover and the lack of easily accessible land suitable for ricepaddy agriculture prohibited human settlement and agriculture development.

The first clear signal of human activities in the study area is recognized in the LTY core at $48 \mathrm{~cm}$, where the sudden increase in charcoal concentration could be interpreted as a strong evidence of using fire at regional to local scale for very high-intensity clearance of the forest vegetation in order to gain land for agriculture and human habitation. This initial activity phase is followed by a longer phase of landscape management. This phase is mainly characterized by lower percentages of AP and higher percentages of NAP (particularly of Poaceae and Artemisia) and high percentages of pine pollen, suggesting more open landscape and wet rice agriculture.
The age model of the LTY core suggests that the onset of intensive human activity in the study area occurred after $c .3600$ cal. yr BP. Our result is consistent with land cover model simulations which suggest that in Zhejiang Province deforestation was well underway by 3000 years ago and landscape in most areas was impacted by agriculture (Boyle et al., 2011; Olofsson and Hickler, 2008). We suppose that people were compelled to seek land at high-elevation mountainous areas by increasing population, especially after a booming of population during the flourish of Yue state $(\mathrm{Li}, 1997)$. The initial increase to the first peak in $34-40 \mu \mathrm{m}$ Poaceae pollen at c. 2100 cal. yr BP reflects local rice cultivation expansion, which is synchronous with the onset of profoundly widespread human impacts and apparently extensive agriculture in the Lower Yangtze (Atahan et al., 2008). This is probably due to technological advances in agriculture, such as spread of cow plough and usage of iron farm implements (Rostoker et al., 1983).

\section{Conclusion}

The LTY core sediment lithology and pollen assemblage composition between c. 8200 and 5600 cal. yr BP reflect a fluvial to lacustrine sedimentary environment and local growth of a dense alder forest and fern cover in the forest understory. The mountain slopes were covered with undisturbed subtropical forests dominated by evergreen broadleaved taxa. The record indicates a moist and warm subtropical climate corresponding to the early Holocene climatic optimum controlled by higher than present summer solar insolation and stronger than present monsoons.

Pollen and sedimentary records suggest a marshy wetland developed after $c$. 5600 cal. yr BP, likely resulting from reduced river water supply and gradual weakening of the EASM caused by a decrease in Northern Hemisphere summer insolation. Two intervals of swamp expansion (c. 4600-4400 and c. 3300-3000 cal. yr BP) fall within two well distinguished intervals of monsoon weakening (dry climate events) identified in the regional speleothem records.

The human activities did not leave visible traces in the LTY core pollen and charcoal records prior to $c .3600$ cal. yr BP, suggesting overall anthropogenic impact was quite limited which is in contrast to the prosperous agriculture in Zhejiang and lower Yangtze regions since $\sim 8000 \mathrm{yr}$ BP. Our results suggest that humans had intensive involvement in forest clearance and landscape opening using fire after c. $3600 \mathrm{cal}$. yr BP, in line with the substantial increase in population in Zhejiang Province. The clear signal of in situ rice cultivation development after c. 2100 cal. yr $\mathrm{BP}$ is synchronized with profound human activities and extensive agriculture in Lower Yangtze area, which could be the result of widespread availability of iron tools and cow plough.

\section{Acknowledgements}

We cordially thank Dr Robert Spengler and Dr Christian Leipe for their critical review and language improvements in the current version of this manuscript. Thanks are also due to Meiling Man for laboratory help and to Guangqi Zhu and Yuanfu Yue for fieldwork assistance. Ma Ting further expresses her gratitude to Dr Dieter Demske for his valuable consultations and help with pollen identification and to all other members of the Palaeontology Branch and to the Centre for International Cooperation of the FUB for friendly and supportive atmosphere during her stay.

\section{Funding}

This work was supported by the National Natural Science Foundation of China (Grant No. 41230101). Ma Ting acknowledges China Scholarship Council for the financial support of her PhD fellowship at the Free University Berlin (FUB). Pavel Tarasov's research is financed via the German Science Foundation (DFG) Heisenberg Programme (TA 540/5). 


\section{References}

An ZS, Porter SC, Kutzbach JE et al. (2000) Asynchronous Holocene optimum of the East Asian monsoon. Quaternary Science Reviews 19: 743-762.

Atahan P, Itzstein-Davey F, Taylor D et al. (2008) Holocene-aged sedimentary records of environmental changes and early agriculture in the lower Yangtze, China. Quaternary Science Reviews 27: 556-570.

Bengtsson L and Enell M (1986) Chemical analysis. In: Berglund BE (ed.) Handbook of Holocene Palaeoecology and Palaeohydrology. New York: John Wiley \& Sons, pp. 423-451.

Berger A and Loutre MF (1991) Insolation values for the climate of the last 10 million years. Quaternary Science Reviews 10: 297-317.

Blaauw M (2010) Methods and code for 'classical' age-modelling of radiocarbon sequences. Quaternary Geochronology 5: 512-518.

Bond G, Kromer B, Beer J et al. (2001) Persistent solar influence on north Atlantic climate during the Holocene. Science 294: 2130-2136.

Boyle JF, Gaillard MJ, Kaplan JO et al. (2011) Modelling prehistoric land use and carbon budgets: A critical review. The Holocene 21: 715-722.

Cao ZH, Ding JL, Hu ZY et al. (2006) Ancient paddy soils from the Neolithic age in China's Yangtze River Delta. Naturwissenschaften 93: 232-236.

Chen QY (1985) Brief Records of Zhejiang Geography. Hangzhou: Zhejiang Education Press (in Chinese).

Clark JS (1988) Particle motion and the theory of charcoal analysis: Source area, transport, deposition, and sampling. Quaternary Research 30: 67-80.

COHMAP Members (1988) Climatic changes of the last 18,000 years: Observations and model simulations. Science 241: 1043-1052.

Cosford J, Qing HR, Yuan DX et al. (2008) Millennial-scale variability in the Asian monsoon: Evidence from oxygen isotope records from stalagmites in southeastern China. Palaeogeography, Palaeoclimatology, Palaeoecology 266: 3-12.

Dykoski CA, Edwards RL, Cheng H et al. (2005) A high-resolution, absolute-dated Holocene and deglacial Asian monsoon record from Dongge Cave, China. Earth and Planetary Science Letters 233: 71-86.

Fuller DQ, Harver E and Qin L (2007) Presumed domestication? Evidence for wild rice cultivation and domestication in the fifth millennium BC of the Lower Yangtze region. Antiquity 81: 316-331.

Fuller DQ, Qin L, Zheng Y et al. (2009) The domestication process and domestication rate in rice: Spikelet bases from the lower Yangtze. Science 323: 1607-1610.

Grimm EC (1987) CONISS: A Fortran 77 program for stratigraphically constrained cluster analysis by the method of incremental sum of squares. Computers \& Geosciences 13: $13-35$.

Grimm EC (1991) TILIA and TILIAGRAPH. Springfield, IL: Illinois State Museum.

Guojia Wenwuju (2009) Atlas of Chinese Cultural Relics: Zhejiang Volume. Beijing: Cultural Relics Publishing House (in Chinese).

Haug GH, Hughen KA, Sigman DM et al. (2001) Southward migration of the intertropical convergence zone through the Holocene. Science 293: 1304-1308.

Heiri O, Lotter AF and Lemcke G (2001) Loss on ignition as a method for estimating organic and carbonate content in sediments: Reproducibility and comparability of results. Journal of Paleolimnology 25:101-110.

Hong YT, Jiang HB, Liu TS et al. (2000) Response of climate to solar forcing recorded in a 6000 -year $\delta^{13} \mathrm{O}$ time-series of Chinese peat cellulose. The Holocene 10: 1-7.
Hong YT, Wang ZG, Jiang HB et al. (2001) A 6000-year record of changes in drought and precipitation in northeastern China based on a $\delta^{13} \mathrm{C}$ time series from peat cellulose. Earth and Planetary Science Letters 185: 111-119.

Hu C, Henderson GM, Huang J et al. (2008) Quantification of Holocene Asian monsoon rainfall from spatially separated cave records. Earth and Planetary Science Letters 266: 221-232.

Huang KY, Zheng Z, Liao WB et al. (2014) Reconstructing late Holocene vegetation and fire histories in monsoonal region of southeastern China. Palaeogeography, Palaeoclimatology, Palaeoecology 393: 102-110.

Innes JB, Zong Y, Chen Z et al. (2009) Environmental history, palaeoecology and human activity at the early Neolithic forager/cultivator site at Kuahuqiao, Hangzhou, eastern China. Quaternary Science Reviews 28: 2277-2294.

Institute of Botany, Academy Sinica (IBAS) (1960) Chinese Vegetation Regionalization. Beijing: Science Press (in Chinese).

Institute of Botany and South China Institute of Botany, Academy Sinica (IBSCIBAS) (1982) Angiosperm Pollen Flora of Tropic and Subtropic China. Beijing: Science Press (in Chinese).

Jiang HQ (1980) Distributional features and zonal regularity of vegetation in Yunnan. Acta Botanica Yunnanica 2: 142-151.

Jiang LP and Liu L (2006) New evidence for the origins of sedentism and rice domestication in the Lower Yangzi River, China. Antiquity 80: 355-361.

Jiang LP, Zheng YF, Fang XM et al. (2004) Kuahuqiao. Beijing: Cultural Relics Publishing House.

Kutzbach JE (1981) Monsoon climate of the early Holocene: Climate experiment with the Earth's orbital parameters for 9000 years ago. Science 214: 59-61.

Lee CY, Liew PM and Lee TQ (2010) Pollen records in southern Taiwan, implications of the variation of East Asian summer monsoon during the Holocene. The Holocene 20: 81-89.

Leipe C, Demske D, Tarasov PE et al. (2014) Potential of pollen and non-pollen palynomorph records from Tso Moriri (TransHimalaya, NW India) for reconstructing Holocene limnology and human-environmental interactions. Quaternary International 348: 113-129.

Li DW, Chen HW, Shi FQ et al. (2008) Biological and ecological characteristics and geographical distribution of Alnus nepalensis yunnanensis. Forest Inventory and Planning 33: 25-28.

Li ZT (1997) The Rebirth of a king's population thought and policy during the Warring States period. Journal of Hangzhou University 27: 54-60 (in Chinese).

Liew PM, Huang SY and Kuo CM (2006a) Pollen stratigraphy, vegetation and environment of the last glacial and Holocene - A record from Toushe Basin, central Taiwan. Quaternary International 147: 16-33.

Liew PM, Lee CY and Kuo CM (2006b) Holocene thermal optimal and climate variability of East Asian monsoon inferred from forest construction of a subalpine pollen sequence, Taiwan. Earth and Planetary Science Letters 250: 596-605.

Liew PM, Wu MH, Lee CY et al. (2014) Recent 4000 years of climatic trends based on pollen records from lakes and a bog in Taiwan. Quaternary International 349: 1-8.

Lister G, Kelts K, Chen KZ et al. (1991) Lake Qinghai, China: Closed-basin lake levels and the oxygen isotope record for ostracoda since late Pleistocene. Palaeogeography, Palaeoclimatology, Palaeoecology 84: 141-162.

Ma C, Zhu C, Zheng C et al. (2009) Climate changes in East China since the last Late-glacial inferred from high-resolution mountain peat humification records. Science in China Series D: Earth Sciences 52: 118-131.

Maher LJ, Jr (1981) Statistics for microfossil concentration measurements employing samples spiked with marker grains. Review of Palaeobotany and Palynology 32: 153-191. 
Nakagawa T, Brugiapaglia E, Digerfeldt G et al. (1998) Densemedia separation as a more efficient pollen extraction method for use with organic sediment samples: Comparison with the conventional method. Boreas 25: 15-24.

Olofsson J and Hickler T (2008) Effects of human land-use on the global carbon cycle during the last 6,000 years. Vegetation History and Archaeobotany 17: 605-615.

Peng HH, Zheng Z, Zheng YW et al. (2015) Holocene vegetation changes and human activities revealed by a peat sediment core in Gaoyao, Zhaoqing. Quaternary Sciences 35: 742-754 (in Chinese with English Abstract).

Qin JG, Taylor D, Atahan P et al. (2011) Neolithic agriculture, freshwater resources and rapid environmental changes on the lower Yangtze, China. Quaternary Research 75: 55-65.

Rasband WS (1997-2014) ImageJ US, National Institutes of Health, Bethesda, MD. Available at: http://imagej.nih.gov/ij/.

Reimer PJ, Bard E, Bayliss A et al. (2013) IntCal13 and Marine13 radiocarbon age calibration curves, $0-50,000$ years cal BP. Radiocarbon 55: 1869-1887.

Rostoker W, Bronson B, Dvorak J et al. (1983) Casting farm implements, comparable tools and hardware in ancient China. World Archaeology 15: 196-210.

Shu JW, Wang WM, Jiang LP et al. (2010) Early Neolithic vegetation history, fire regime and human activity at Kuahuqiao, Lower Yangtze River, East China: New and improved insight. Quaternary International 227: 10-21.

Silva F, Stevens CJ, Weisskopf A et al. (2015) Modelling the geographical origin of rice cultivation in Asia using the rice archaeological database. PLoS ONE 10: e0137024.

Stanley DJ and Chen Z (1996) Neolithic settlement distribution as a function of sea level controlled topography in the Yangtze Delta, China. Geology 12: 1083-1086.

Stockmarr J (1971) Tablets with spores used in absolute pollen analysis. Pollen et Spores 13: 614-621.

Tarasov PE, Jin GY and Wagner M (2006) Mid-Holocene environmental and human dynamics in northeastern China reconstructed from pollen and archaeological data. Palaeogeography, Palaeoclimatology, Palaeoecology 241: 284-300.

Wang FH, Chie NF, Zhang YL et al. (1995) Pollen Flora of China. 2nd Edition. Beijing: Science Press (in Chinese).

Wang WM, Ding JL, Shu JW et al. (2010) Exploration of early rice farming in China. Quaternary International 227: 22-28.

Wang YJ, Cheng H, Edwards LR et al. (2005) The Holocene Asian monsoon: Links to solar changes and North Atlantic climate. Science 308: 85-857.

Webster PJ, Magana VO, Palmer TN et al. (1998) Monsoons: Processes, predictability, and the prospects for prediction, in the TOGA decade. Journal of Geophysical Research 103: 14451-14510.

Wei DY, Chen YC, Wang JJ et al. (1995) A paleoclimatic record for a period of the past 13 thousand years from the drilling core of the Ha01 hole in Hamaertai Soda Lake of Inner
Mongolia, China. Geology of Chemical Minerals 17: 73-81 (in Chinese with English Abstract).

Weisskopf A, Qin L, Ding JL et al. (2015) Phytoliths and rice: From wet to dry and back again in the Neolithic lower. Antiquity 89: 1051-1063.

Whitlock C and Larsen C (2001) Charcoal as a fire proxy. In: Smol JP, Briks HJB and Last WM (eds) Tracking Environmental Change Using Lake Sediments. Dordrecht: Kluwer Academic Publishers, pp. 43-67.

Wu WX and Liu TS (2004) Possible role of the 'Holocene Event 3 ' on the collapse of Neolithic cultures around the central plain of China. Quaternary International 117: 153-166.

Wu Y, Jiang L, Zheng YF et al. (2014) Morphological trend analysis of rice phytolith during the early Neolithic in the Lower Yangtze. Journal of Archaeological Science 49: 326-331.

Wu ZY (1980) Vegetation of China. Beijing: Science Press (in Chinese).

Wu ZY and Raven PH (eds) (1999) Flora of China 4: Cycadaceae through Fagaceae. Beijing: Science Press.

Yang SX, Zheng Z, Huang KY et al. (2012) Modern pollen assemblages from cultivated rice fields and rice pollen morphology: Application to a study of ancient land use and agriculture in Pearl River Delta, China. The Holocene 22: 1393-1404.

Yue YF, Zheng Z, Huang KY et al. (2012) A continuous record of vegetation and climate change over the past 50,000 years in the Fujian Province of eastern subtropical China. Palaeogeography, Palaeoclimatology, Palaeoecology 365-366: 115-123.

Yue YF, Zheng Z, Rolett BV et al. (2015) Holocene vegetation, environment and anthropogenic influence in the Fuzhou Basin, southeast China. Journal of Asian Earth Sciences 99: 85-94.

Zhang JW, Chen FH, Holmes JA et al. (2011) Holocene monsoon climate documented by oxygen and carbon isotopes from lake sediments and peat bogs in China: A review and synthesis. Quaternary Science Reviews 30: 1973-1987.

Zhao Y, Hölzer A and Yu ZC (2007) Late Holocene natural and human-induced environmental change reconstructed from peat records in eastern central China. Radiocarbon 49: 789-798.

Zhao Y, Yu ZC, Chen FH et al. (2009) Vegetation response to Holocene climate change in monsoon-influenced region of China. Earth-Science Reviews 97: 242-256.

Zheng Z and Li QY (2000) Vegetation, climate, and sea level in the past 55,000years, Hanjiang Delta, Southeastern China. Quaternary Research 53: 330-340.

Zhou WJ, Yu XF, Jull AJT et al. (2004) High-resolution evidence from southern China of an early Holocene optimum and a mid-Holocene dry event during the past 18000 years. Quaternary Research 62: 39-48.

Zong Y, Chen Z, Innes JB et al. (2007) Fire and flood management of coastal swamp enabled first rice paddy cultivation in east China. Nature 449: 459-462. 